\title{
Monthly Review | Spain, Economic Crisis, and the New Enclosure of the Reproductive Commons
}

Sandra Ezquerra more on Labor, Women's Studies/Feminism

Sandra Ezquerra received her $\mathrm{PhD}$ in sociology from the University of Oregon and is currently associate professor at Universitat de Vic, in Barcelona. She would like to thank Jaume Franquesa, Marion Werner, Daniel Albarracín, and Bibiana Medialdea for their careful reading of different drafts of the article and their extremely helpful feedback. Since her first language is not English, she also thanks Brian Anglo and Andreu Coll for their help and support translating this edition of the text.

In the past few years numerous authors have examined how the current economic crisis in Spain has differential impacts on women and men.1 While this is important to show, this article's goal is to make the leap from a mere description of the gendered effects of the crisis, to an analysis of some of the very gendered processes that shape it at its core. In other words, the intent is to understand how both the crisis itself and the ways the state manages it are structurally shaped by gender. 2

This analysis will be based on a critical genealogy of the classical Marxian concept of primitive (or primary) accumulation, which will be applied to the current economic context in Spain. It will be carried out in two different ways. First, following Marxian theory and some feminist theorists, it will be argued that primitive accumulation crops up continuously throughout the history of capitalism as a mechanism to overcome crises of accumulation. Second, based upon several feminist authors' critical analysis of the concept, it will be maintained that the primitive accumulation, or accumulation by dispossession, currently taking place in Spain is deeply shaped by gender in the sense that one of the main strategies capital develops, and the state implements, is to push the responsibilities that the state formerly had for public welf are back onto women and households. This is what Maria Mies has called "rehousewifization," 3 and what will be called here a "new enclosure of the reproductive commons." This captures the fact that what had partially become a public and collectively shared responsibility for reproduction is now being imposed-as a result of the neoliberal management of economic crisis-on women (individuals) and their unpaid labor in the household (families). Spanish labor market and household data indicate that there is an important difference between the gendered workings of primitive accumulation from the fifteenth-to-eighteenth centuries, and current ones. Although one of its effects back then was to exclude many women from the pool of wage laborwhich is not meant to deny the huge role that women played in wage-based proletarianization during the Industrial Revolution-at present it compels their entry into the labor market while simultaneously exacerbating their unpaid reproductive burden at home. Accumulation by dispossession today places Spanish women in the paradoxical situation of becoming crucial economic actors while reinforcing their traditional care-giving roles in order to make up for the state's retreat from the public arena.

\section{From Primitive Accumulation to Accumulation by Dispossession}

Following the earlier classical economists, Karl Marx theorized what he called "so-called 'primary accumulation" (mistranslated in the English edition of Capital as "primitive accumulation"), occurring in England between the fifteenth and eighteenth centuries.4 He saw this as constituting a precondition for the full development of capitalist relations of production and accumulation. Some of its best known episodes were the enclosures, including the usurpation of communal lands; the expropriation of Church property; the slave trade; the pillage of the Americas and the East Indies; and the "extirpation, enslavement, and entombment in mines" of indigenous peoples.5 Common to all of this was the forceful separation of actual producers from their means of production and the concentration of the latter in the hands of the emerging capitalist class. The transformation of peasantry into wage-workers or proletarians, and the conversion of their surplus labor into capital, constituted the essential premise behind the capitalist accumulation. All of these processes were made possible to a great extent by state complicity. 
Although Marx dealt with primary accumulation largely in terms of the historical preconditions of capitalism (abstracting from them in his analysis of capitalism's internal laws of motion), these practices have continued throughout the history of capitalism and are continuously brought up to date. David Harvey's discussion of this in The New Imperialism was inspired in part by Luxemburg's thesis that capitalism needed the perpetual incorporation of non-capitalist territories. Primitive accumulation was thus a continually reoccurring reality within historical capitalism in the form of colonial politics, the international credit system, and wars. European imperialism saved capitalism from its own crisis through the expansion of markets for capitalist commodities and the plundering of labor force and resources beyond European borders. 6

Harvey suggests that during overaccumulation crises, the predatory practices of capitalism speed up and take the form of what he calls "accumulation by dispossession." The credit system has intensified as an accumulation mechanism through the centralization of capital, corporate fraud, attacks on pension funds, and speculation. In addition, the global commons are being enclosed in new ways. Some instances of this are the development of intellectual property rights, which are used against the very same people that produced the materials; the depletion of global environmental commons such as land, air, and water; the commodification of former public assets such as universities and public services; and the deregulation and privatization of common property rights including public pensions, social services and public health systems. Other mechanisms of accumulation by dispossession have been implemented by structural adjustment programs and through the creation of debt crises in many countries. These processes make up a new wave of enclosures of the commons which, as in the past, are enforced with state complicity and against people's will.7

\section{Gendering Accumulation by Dispossession}

In recent decades, several authors have reviewed Marx, Luxemburg, and Harvey's work from a critical feminist perspective. 8 According to Maria Mies, for instance, women, nature, and the peoples of impoverished countries have made up the invisible base upon which the processes of capitalist accumulation have been historically established.9 Their subordination and exploitation continue to be essential premises underlying the reproduction of the current model and, therefore, it is crucial to understand the interactions, both historical and present, between the sexual, social, and international divisions of labor.10 Without denying the importance of the separation of producers from their means of production, Mies takes a step further:

The strategy of dividing the economy up into 'visible' and 'invisible' sectors ... has been the method of the capitalist accumulation right from its beginning. The invisible parts were per definition excluded from the 'real' economy. But they constituted in fact the very foundations for the visible economy. These excluded parts were/are the internal and external colonies of capital: the housewives in the industrialized countries and the colonies in Africa, Asia and Latin America.11

Along similar lines, Silvia Federici questions Marx's understanding of primitive accumulation as exclusively focalized on the proletariat and the development of commodity production. In her view, primitive accumulation also needs to be understood as the development of a new sexual division of labor that created divisions and hierarchies within the working class, therefore binding women to the reproduction of the labor force, and leading to their partial exclusion from wage labor and their subordination to men. Capitalism was based not simply on proletarianization of working class men and women, but also on the fictitious separation between productive and reproductive work, their attribution to men and women respectively, and the invisibilization and subordination of women for the sake of men. Women were not only dispossessed of their control of the means of production, but also of control over their own bodies. The sixteenth- and seventeenth-century witch hunt, for instance, was as important as the colonization and expropriation of European peasants from their land, since it destroyed "the control that women had exercised over their reproductive function," 12 and promoted the creation of a new subject/object that during the nineteenth century would come to be known as "housewife"-though, it should be added, that this was always much more a middle- and upper-class reality than one that penetrated to working-class women. 
In Federici's view, primitive accumulation has been a universal process the ruling class has launched during each capitalist crisis in order to reduce wage labor costs and hide women's and colonial subjects' exploitation.13 During the foundational context it drove women's impoverishment, loss of autonomy, and their subordination to the so-called productive economy. In recent decades, institutions such as the World Bank and the International Monetary Fund have brought accumulation by dispossession up to date through the imposition of programs based on social cutbacks, privatizations, and austerity that foster "the rationalization of social reproduction aimed at destroying the last vestiges of communal property and community relations, and thereby impose more intense forms of labor exploitation."14

Nancy Hartsock has also theorized contemporary global accumulation of capital as a new momentum of primitive accumulation which violently divests a growing number of people of their ability to produce their own subsistence and guarantees the concentration of capital in increasingly fewer hands. Far from being gender neutral, the current processes of accumulation by dispossession drive women's entry into paid work and use it for the creation of the feminized working-class contemporary capitalist flexible accumulation requires. As women have been drawn into the international labor force, men have also been forced increasingly to work under conditions previously primarily associated with women workers (such as growing flexibility and precariousness and part-time jobs).15 The feminization of the labor force therefore causes increasing degradation of the working class. It also poses, according to Hartsock, contradictory problems and possibilities for women. On the one hand, they have been entering global capitalism in disadvantageous conditions in comparison with men. On the other hand, this incorporation increases their autonomy and allows them to free themselves from some forms of patriarchal oppression.

Nancy Hartsock shows that current accumulation by dispossession operates in irregular waves and through numerous interrelated processes, some of which have deepened during the past thirty years. First, it increases social inequalities and impoverishment on a global scale. Second, the breaking and transformation of the social contract redefines social relations between political power, capital, labor, and, among others, the population's expectation of common goods and public services. Third, current accumulation by dispossession also entails a transformation of the processes of social reproduction and the whole set of social relations that shape them. These three processes are possible due to a number of ideological changes stemming from the rise of both neoliberalism and neoconservatism.

\section{Economic Crisis and the Enclosure of the Reproductive Commons in Spain}

Joan Acker is correct when she states that the starting point of our examination must be "the material conditions of life and the relations involved in the production of those conditions in particular historical moments."16 Taking this into consideration, and building upon Mies, Federici and Hartsock's arguments, some of the dimensions of Spain's current economic crisis will be analyzed. In doing so, the transformations that have taken place in the labor market and reproduction relations in recent decades will be specifically focused upon. The thesis is that the crisis leads to a new momentum of accumulation by dispossession profoundly marked by gender; one in which capital attempts to leave the crisis behind through a new enclosure of the reproductive commons. This process, nevertheless, takes place in different ways than it did in the past. While reproductive responsibilities are being returned to the fundamental invisible base of the economic system (i.e., women's unpaid labor), capital at the same time is increasingly resorting to women's paid labor in the job market. However, this analysis differs from Hartsock's, since it is argued that the current crisis does not unequivocally emancipate women in Spain through their entry into the labor market but, on the contrary, it revives traditional gender oppressions and merges them with more recent ones.

Focusing specifically on Spain, it is worth briefly emphasizing two issues: the singularities of both its current economic crisis and the history of its welf are state. While the outbreak of the Spanish economic crisis in 2008 resulted from the international financial crisis, its effects were aggravated by a number of previously existing factors. In the past thirty years, Spain has undergone a similar neoliberal restructuring to the rest of the world. Some of the particular legacies of the forty-year-long dictatorship which ended in 1978 , however, are the enormous power retained by conservative authoritarian forces, a highly precarious labor market, huge social inequalities, a very powerful banking system in comparison with the country's 
European neighbors, a highly regressive and inadequate tax system, and a poor social protection structure. In the mid-1970s Spain was far below the European standards of social welf are and the first democratic governments had to face the challenge to build social-welf are structures in an international context that pushed toward their dismantling.

While public social spending increased during the 1980s, it started to decline again after Spain joined the European Union in 1993. The Maastricht Treaty requirement of deficit reduction was pursued by cutting back social spending, and by 2002 the Spanish social spending deficit was back to its 1975 level of 7.2 percent of GDP.17 Entry into the European Community and the Monetary Union as a semi-peripheral economy put large parts of the Spanish economy in the hands of foreign capital, limited national autonomy for macroeconomic decisions, consolidated a dependent productive model, caused productivity to stagnate, and turned Spain's foreign deficit into one of the highest in the world.18 Massive privatization of public companies strengthened in turn the oligarchic character of the economy, which thereafter increasingly specialized in finances, tourism, services, and construction.

The construction sector grew exponentially between 1995 and 2007 due to both strong public support (through investments and tax benefits) and exorbitant private indebtedness. Spain is one of the countries with the largest social inequalities in Europe and where private indebtedness has grown the most. The financialization process has acted as an income transfer device: whereas in 1960 wages' share of national GDP was 68 percent, in 2008 it had fallen to 60.21 percent and by 2012 it had gone down to 52.3 percent. In addition, during the ten years prior to the bursting of the housing bubble, families' and businesses' indebtedness tripled from 61 percent of income in 1997 to 139 percent in 2007.19 The bubble burst as a result of the exorbitant growth of private debt; the impossibility of indef inite inflation of housing prices; the inability to control external imbalances due to external markets' loss of trust; increasing social inequalities that helped to weaken internal markets; financial, monetary, and tax policies aimed at stimulating indebtedness; and the indifference of both the right-wing and social- democratic Spanish administrations toward the unsustainability of a growth model based on "bricks and mortar."

The Spanish government has made a considerable effort since 2008 to deal with the crisis, reduce skyrocketing unemployment rates, and help the banking system to pay its foreign creditors. While it soon dropped its timid neo-Keynesian policies to create jobs, by mid-2009 Spain was the OECD country that had spent the most public resources on rescuing banks (2 percent of GDP).20 Within a short period of time, the public deficit shot up and so did the public debt, resulting in the so-called debt crisis beginning in 2010 . The government has had to resort to "the markets" (banks and investment groups), resulting in exorbitant interest rates on public debt, forcing severe structural reforms in areas such as the labor market, public pensions, universities, the health care system, and social programs.

At the end of 2013 Spain's unemployment rate was 26 percent, yet the government was still set on achieving the EU and the Spanish Constitution mandates to keep the deficit below 3 percent through the suppression of already meager basic public benefits and services. Whereas in 2010 Spanish GDP was 94 percent of the EU-15 average, its social spending was only 72 percent of the EU-15 average and has drastically declined since then. Some of the biggest weaknesses of the Spanish welf are state are in family support services. For instance, only 10 percent of children aged two years or less in Spain benef it from public daycare (in comparison with 28 percent in the EU-15 and 58 percent in Sweden). In 2004 only 2 percent of potential clients received in-home support services for the elderly and disabled in comparison with EU-15's 18 percent and Sweden's 23 percent. As opposed to other welf are regimes in Europe, the Spanish social system has largely relied on families, and particularly women, to make up for its deficiencies.21 As detailed below, this scenario is worsening with the current economic crisis and triggering transformations both in the labor market and in reproduction relations.

As shown in Chart 1, the Spanish female economically active population rate has grown markedly since the 1970s: whereas in 1976 it was 28.67 percent, by 1994 it had increased to 37.09 percent. Since the early 2000 s it has continued to increase steadily and this trend did not change after the outbreak of the crisis in 2008. In the third quarter of 2013 women's economic activity rate was 53.31 percent, almost doubling the figures of the mid-1970s. This contrasts with the decline of male economic activity in recent decades: the 
1976 male activity rate was as high as 77.80 percent, but thereafter followed a constantly declining trend until the mid-1990s. It reached its lowest point, 62.75 percent, in 1995. One year later, however, it started to climb again as a result of the exponential growth of the construction sector and the housing bubble, reaching a new peak of 69.21 percent in 2008 . Since the outbreak of the crisis, nevertheless, it has not stopped dropping and by the third quarter of 2013 it had fallen to 65.90 percent,22 which means that it is not only lower than in 2008, but twelve points lower than in 1976. The massive destruction of male employment over the past few decades, and particularly in the past five years, 23 has been paralleled by an intensification of women's incorporation into the labor market and, presumably, growing dependency of families on female wages.

Chart 1. Economic Activity Rates by Gender in Spain, 1976-2012.

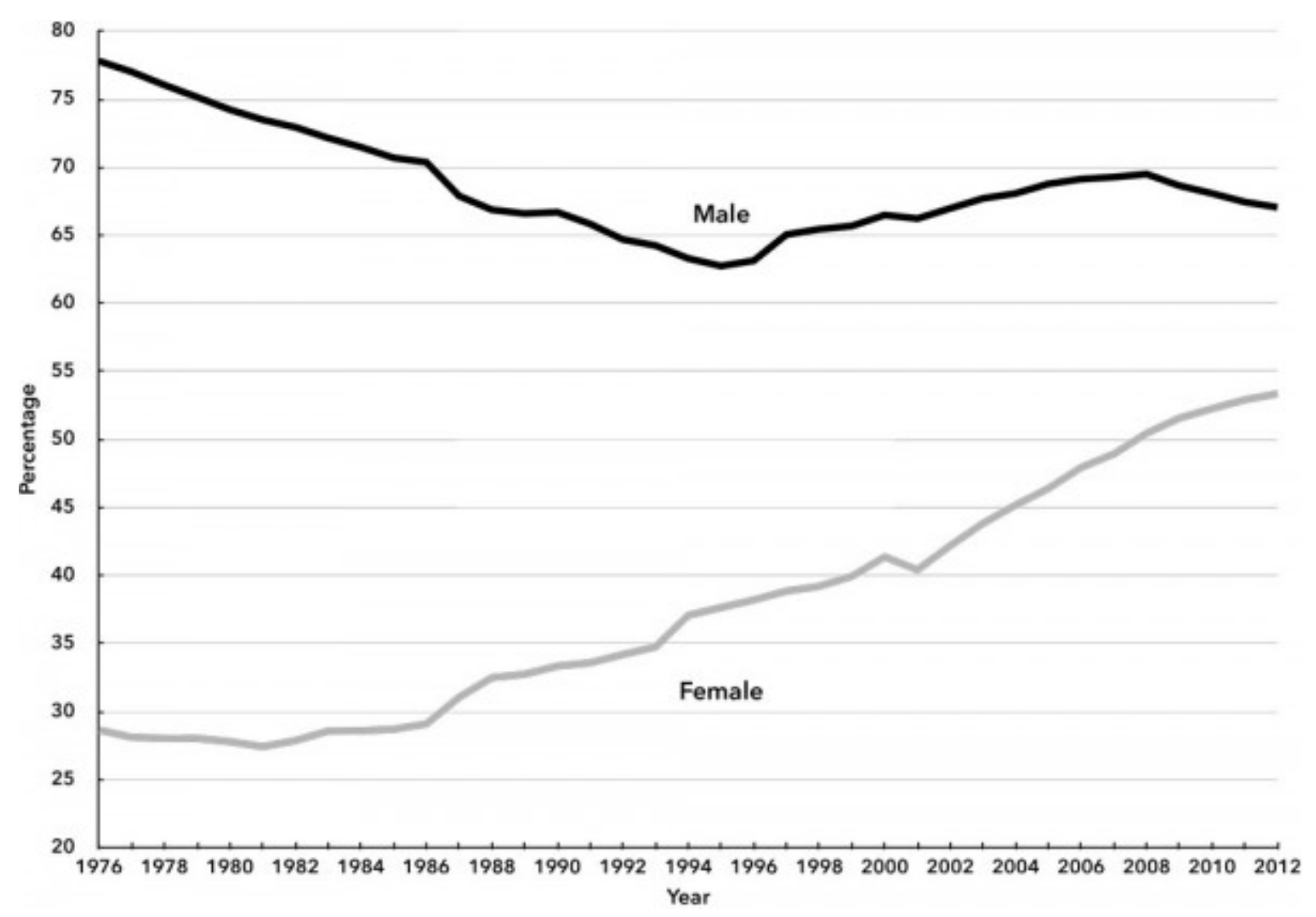

Sources: Compiled by the author from Spanish Active Population Survey data. The so-called active population is the total amount of people who are sixteen and older and either have a job or are unemployed and look for a job. The labor activity rate results from dividing the total amount of the active population by the total amount of population who are sixteen and older. It is published every quarter by the Spanish National Institute of Statistics.

If we turn to the employment-population ratio, as shown in Chart 2, in 1976 the male and female rates were 71.60 percent and 28.39 percent respectively. Although they both declined up to the mid-1980s, male employment rates did so much more rapidly, falling almost 15 points by 1985 , while women's rates fell by half of this figure in the same period. Since then, the predominant trend has been for the male employmentpopulation ratio to decline, rising occasionally during periods of economic growth such as the already mentioned housing bubble, but never recovering its mid-1970s level. By 2007 it was 64.86 percent and has sharply declined again since, reaching 50.66 percent in the third quarter of 2012. In contrast, the female ratio has steadily grown since the mid-1980s despite a brief interruption in the early 1990s. In 1993 it was 25.5 percent, but by 2007 , just before the outbreak of the crisis, it had gone up to 43.63 percent. Since then it has lost three points, reaching 40.3 percent in 2012 , in contrast with the recent fourteen-point decline in the male ratio. If this trend continues, in a few years men and women may have an equal presence in the Spanish labor market. Needless to say, equality in terms of numbers, but not conditions, is meant: women in Spain continue to suffer wage discrimination, vertical and horizontal segregation in the labor market, and, 
among other problems, are heavily concentrated in part-time and temporary jobs.24

Chart 2. Employment-Population Ratio by Gender in Spain, 1976-2012

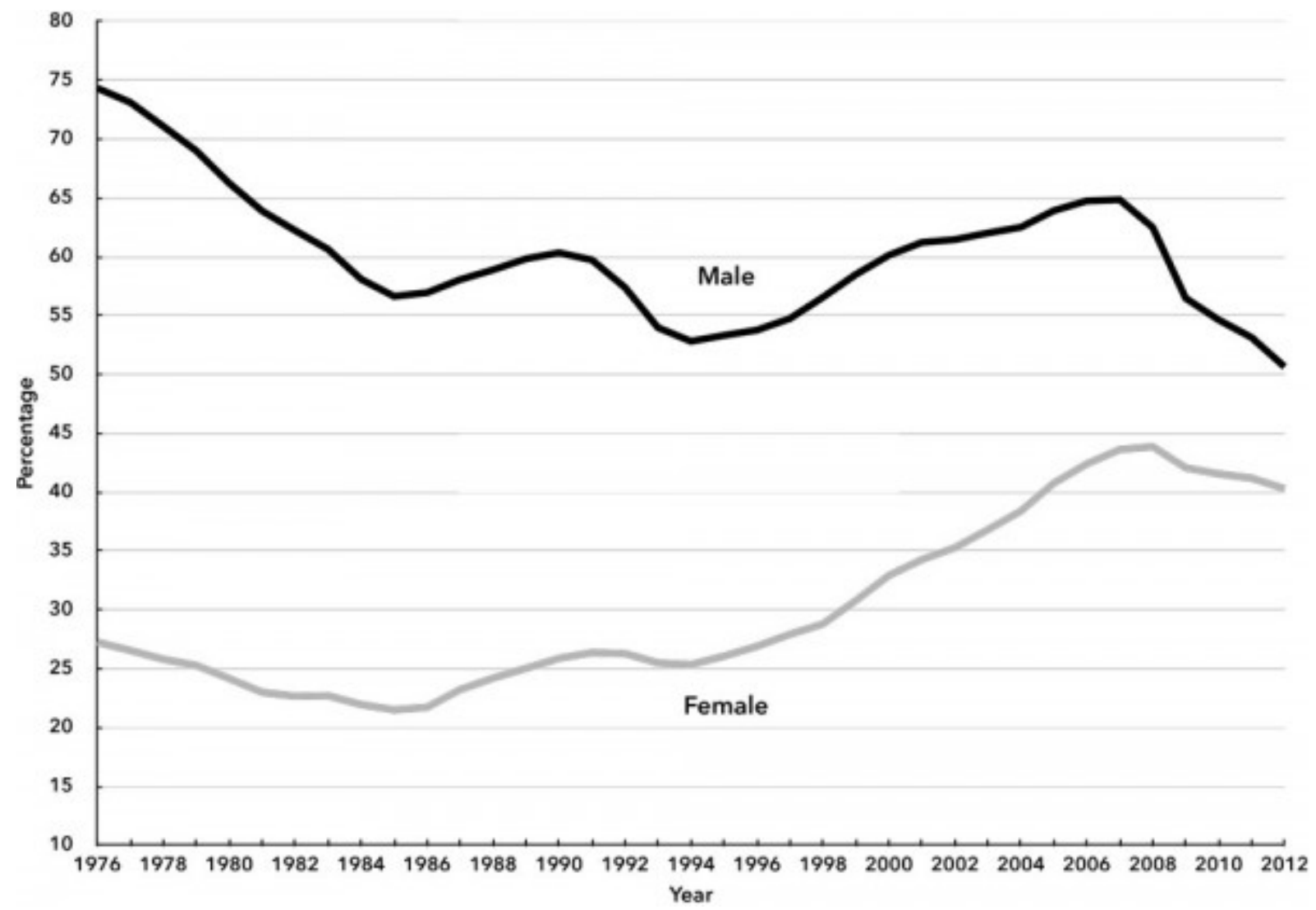

Sources:Compiled by the author from Spanish Active Population Survey data. The employment rate is the result from dividing the total amount of people who have a job by the total amount of people who are sixteen or older. It is published every quarter by the Spanish National Institute of Statistics.

In contrast to the decreasing availability of Spanish women to shoulder domestic and caregiving responsibilities, life-expectancy growth and population-ageing in recent years have led to increased care needs. First, the proportion of over-sixty-fours has gone up from 10.45 percent in 1975 to 15.11 percent in 1995, 16.80 percent in 2005, and 17.38 percent in 2012. Second, the average age of the Spanish population has increased from 33.13 years in 1975 to 38.12 in 1995, 40.40 in 2005, and 41.24 in 2011. Third, the Spanish Ageing Index has grown from 35.87 percent in 1975 to 81.92 percent in 1995, 108.20 percent in 2005, and 109.53 percent in 2013.25 Lastly, the Elderly Dependency Rate has gone up from 17.29 percent in $1975,22.75$ percent in 1995, 24.81 percent in 2005, and 26.66 percent in 2013.26 This scenario raises the question of the effects the feminization of labor has on the traditional organization of care and social reproduction relations. 27

Neither women's "entry" into the labor market nor men's "exit" from it has led to a redistribution of domestic and care responsibilities within households. According to the 2009-2010 Spanish Time Use Survey, women still spend two hours a day more than men on household work. While the difference decreased by forty minutes between 2002 and 2009 there still exists a difference of 17 percent in terms of participation in unpaid work (74.4 percent for men and 91.9 for women). The same survey shows that 93 percent of women consider themselves to be active in "household and family" while the figure for men is 75 percent and other studies argue that, far from "freeing" women from unpaid domestic work, unemployed men "at home" tend to become an additional burden and responsibility for women who also work in the paid labor market.28

Moreover, families' current expense-cutting strategies and fewer available resources to pay for caregiving and domestic services (mostly conducted by women as well) expand the amount of unpaid household work, increase many women's total work burden, and reinforce their "double shift." 29 In addition, as mentioned above, the feminization of employment and the care void it has generated within households have been 
accompanied during the past decades by a drastic reduction in public social expenditure.30 This retrenchment has severely sharpened in Spain since the outbreak of the 2010 so-called public debt crisis. 31 Formerly public services such as higher education and health care are increasingly managed from a prof itoriented approach and therefore become the object of new enclosures through big hikes in college tuition and, among other things, the introduction of co-payment in public health care. Although in 2006 the previous social-democrat government passed a law providing for universal in-home supportive services for the elderly and the disabled, in 2010 it started to cut down the already meager budget allocation to implement it. The current conservative government has, on the one hand, partially privatized the services and, on the other hand, de facto frozen and in effect repealed the law. Retirement pensions are being cut, retirement age is being raised, and parental leaves and rights are being eroded. Other privatization processes are currently focused on daycare, forcing families to turn to more expensive private services or provide it themselves through free family work.

Although these measures affect the vast majority of the population, some of them have a particularly severe impact on women because of the heavy concentration of women as paid workers in public sectors such as health, education, and social services. Also, women's greater labor and economic vulnerability makes them suffer more acutely the attacks on social expenditure and public social services. The fundamental gender dimension of the current neoliberal response to the crisis, nonetheless, is that as the state retreats from numerous reproductive responsibilities, and without a redistribution of such responsibilities within households, it is families, and particularly women within them, who take on these tasks again in the form of unpaid work in the home or what Mies calls the invisible foundation of the economy, and Federici a new rationalization of social reproduction. This rehousewif ization of reproduction has intensified in Spain since the outbreak of the so-called debt crisis in 2010 and constitutes a central aspect of the current accumulation by dispossession, since it is in households where, as Pérez Orozco points out, the "final adjustment" takes place and allows for a new enclosure of the reproductive commons.32

As feminist critics have argued, the new enclosure of the commons does not take place only through commodification processes, but also through the absorption of the costs of the tip of the capitalist economy by its very invisible base: the reproductive realm. The current systemic crisis accelerates the growth of the care void and the social reproduction crisis engendered throughout years of neoliberal hegemony and drops it on women's backs. Unlike at other times in history, this does not trigger women's retreat from the so-called productive economy, but actually goes hand in hand with an increase in the importance of their economic role. Contrary to what Hartsock suggests, however, women's growing presence in the labor market does not necessarily lead to greater autonomy or liberation from caregiving responsibilities. Rather, their growing role as breadwinners intersects with the recovery of traditional gender roles that seemed to have been partially overcome and the creation of new oppressions through their specific overexploitation in the labor market, and results in an increase in their overall workload. The growth of women's total workload as a result of the neoliberal management of the crisis does not constitute a mere, allegedly inevitable, short-term collateral effect. It results from a political and economic strategy of privatization and rehousewifization of reproduction in order to guarantee the survival of what is considered the real economy that is worth saving.

\section{The New Struggle Over the Reproductive Commons}

There has never been a moment where capitalism has not been fully dependent on unpaid reproductive work done mostly by women. The shape this dependency adopts, nevertheless, varies according to the historical context and, in different degrees, partly as a result of multiple social and political struggles, can be shared by the state and markets. The aim of this article has been to show, through an examination of the Spanish case, that the current economic crisis allows the state to get rid of part of its share of social reproduction and return it to the invisible base where it originally resided: women's unpaid labor. This process can be called a "new enclosure of the reproductive commons." As opposed to some other moments in the history of capitalism, however, this does not result in the exclusion of women from the labor market, but, rather, in their increased presence in it. 
Although this article has focused on some of the material and political dimensions of this new enclosure, further research and analysis are needed in order to understand how this is currently accompanied and facilitated by ideological processes that fuse neoliberal principles of free market, competitiveness, and austerity with the rhetoric and defense of traditional values. As Cindi Katz argues,33 globalization defenders of ten forget the ruling classes' ability to build powerful alliances with patriarchal, homophobic, racist, and religious fundamentalist options.34 The Spanish neoconservative movement has its own particularities, which combine economic liberalism with Spanish patriotism and Christian values. Strongly allied with the Spanish Catholic church, it violently targets issues such as abortion and gay marriage. Currently part of the conservative administration, Spanish neoconservatism argues that the problems of Spanish society do not have political or economic roots, but rather moral ones, and contemporary social crises stem from the destruction of the institution where the most fundamental moral principles reside: the family.35 Conservative leader Javier Arenas, for instance, publicly said in March 2012 that the government should endeavor to "recover family values that have been lost since women have worked." For him, women's return to the home is desirable since "there won't be so many marriage breakdowns, young people will stop going astray, families will fit back into traditional models, and even employment will pick up again" in a process that some have called woman-woman's return to woman-mother.36 Along similar lines, also in 2012 the current Minister of Justice recently stated that motherhood makes women authentically women, and announced the current government's intention to toughen the law on abortion in 2014.37 If successful, the reform would take Spanish women's sexual and reproductive rights back to the 1970s.

Overwhelmed by neoliberal hegemony, many may see the family or morality today as the last ref uges from crisis and dispossession. The Spanish neoconservative right mobilizes these emotions and defends the family, homophobia, and religion, and wars against abortion and amorality. Paradoxically, this parallels a large-scale economic strategy aimed at draining the commons in favor of the ruling classes.38 It is here where the dialectical relationship between the material and ideological realms emerges. The current Spanish conservative administration sharpens the austerity measures launched by the previous social-democrat government and promotes the resurrection of families (and within them women) as a source of support and care that make up for the state's growing evasion of social responsibility. The family they turn to, nevertheless, cannot be of any kind but the heterosexual-patriarchal one, which abides by, and reproduces, the sexual division of labor. This family subsidizes not only the state. It also subsidizes an economic system that is going to rack and ruin. In short, it plays a key role in setting up new strategies of accumulation by dispossession in order to allow capital to survive the crisis that its own contradictions have generated.

While this leads to an erosion of women's and people's social and labor rights, it also poses an opportunity to reflect on the role reproductive, domestic, and caregiving work have historically had in the capitalist system and to imagine new ways of organizing them which do not necessarily entail fresh enclosures of these commons, but the possibility of actually sharing, enjoying, and valuing them. The current crisis is deep, and so is the dispossession. However, important resistance and counterhegemonic phenomena such as the $15 \mathrm{M}$ movement (the Indignados) in Spain, inspired by the Arab Spring, remind us that there is still much hope and, fortunately, still also a lot of history to be written-and made.

Notes 
1. $\hookleftarrow$ Mertxe Larrañaga, "Mujeres, tiempos, crisis: Combinaciones variadas," Revista de Economía Crítica no. 8 (December 2009): 113-20; Isabel Otxoa, "Anticapitalismo: algunas razones des de el feminismo," Viento Sur no. 104 (July 2009): 66-73; Laura Sales, Dones en crisi (Barcelona: Institut Català de les Dones, 2009); Yelena Takhtamanova and Eva Sierminska, "Gender, Monetary Policy: The Case of Nine OECD Countries," Feminist Economics 15, no. 3 (July 2009): 323-53, Lina Gálvez and Juan Torres, Desiguales. Mujeres y hombres en la crisis financiera (Barcelona: Icaria, 2010); Sandra Ezquerra, "Crisis desiguales: miradas feministas a los ef ectos de la crisis," Viento Sur no. 114 (January 2011): 91-98; Sandra Ezquerra, "Women's Crises: Spanish Economic Recession and Political Responses from a Feminist Perspective," in Özlem Onaran and Fred Leplatt, eds., Capitalism: Crisis and Alternatives (London: International Institute for Research and Education, 2011), 179-88; Sandra Ezquerra, "Crisis de los cuidados y crisis sistémica: la reproducción como pilar de la economía llamada real," Investigaciones Feministas 2 (December 2011): 175-87; Sandra Ezquerra, "Sobre viejas y nuevas gestiones de la crisis o el retorno de las mujeres al hogar," Viento Sur no. 121 (March 2012): 87-95.

2. $\hookleftarrow$ See Jennif er Blair, "On Difference and Capital: Gender and the Globalization of Production," Signs: Journal of Women in Culture and Society 36, no. 1 (Autumn 2010): 203-26.

3. $\hookleftarrow$ Maria Mies, Patriarchy and Accumulation on a World Scale (London: Zed Books: 1987).

4. $\hookleftarrow$ Karl Marx, Capital, vol. 1 (New York: Random House, 1976), 873-930. On the history of the notion of primary accumulation see Michael Perelman, The Invention of Capitalism (Durham, NC: Duke University Press, 2000).

5. $\hookleftarrow$ Marx, Capital, vol. 1, 915.

6. $\hookleftarrow$ David Harvey, The New Imperialism (Oxford: Oxford University Press, 2003); Rosa Luxemburg, The Accumulation of Capital (New York: Monthly Review Press, 1956).

7. $\hookleftarrow$ Harvey, The New Imperialism, 137-82.

8. $\hookleftarrow$ Silvia Federici and Leopoldina Fortunati, Il Grande Calibano. Storia del corpo social ribelle nella prima fase del capitale (Milano: Franco Agneli, 1984); Mies, Patriarchy and Accumulation on a World; Nancy Hartsock, "Globalization and Primitive Accumulation," in Noel Castree and Derek Gregory, eds., David Harvey: A Critical Reader (New York: Blackwell, 2006); Silvia Federici, Caliban and the Witch: Women, the Body and Primitive Accumulation (New York: Autonomedia, 2004); Nancy Hartsock, "A New Moment of Primitive Accumulation," Inaugural Conference of the Inkrit Conference, 2011; Christine Keating, Claire Rasmussen, and Pooja Rishi, "The Rationality of Empowerment: Microcredit, Accumulation by Dispossession, and the Gendered Economy," Signs 36, no. 1 (Autumn 2010): 15376; Genevieve LeBaron and Adrienne Roberts, "Toward a Feminist Political Economy of Capitalism and Carcerality," Signs 36, no. 1 (Autumn 2010): 19-44.

9. $\hookleftarrow$ Mies, Patriarchy and Accumulation on a World Scale, xi.

10. $\hookleftarrow$ Ibid., 11.

11. $\hookleftarrow$ lbid., 17.

12. $\hookleftarrow$ Silvia Federici, Caliban and the Witch, 14.

13. $\hookleftarrow$ Ibid, 16-17.

14. $\hookleftarrow \mathrm{lbid}, 9$.

15. $\hookleftarrow$ See also Alicia Girón, "Género, crisis económica y fragilidad financiera: desenredando la madeja," Investigaciones Feministas 2 (December 2011): 11-28.

16. $\hookleftarrow$ Joan Acker, Class Questions: Feminist Answers (Lanham, MD: Rowman \& Littlefield, 2006), 40.

17. $\hookleftarrow$ Vicenç Navarro, El subdesarrollo social de España. Causas y consecuencias (Madrid: Público, 2006), 44. 
18. $\hookleftarrow$ Daniel Albarracín, "La crisis española: entre la tiranía de los mercados financieros, el déficit fiscal, el paro y el recorte de las pensiones," Otra mirada social y económica es possible, February 2010, http://daniloalba.blogspot.com.es.

19. $\hookleftarrow$ Nacho Álvarez, "The Financialization of the Spanish Economy: Debt, Crisis and Social Cuts," paper presented at the Workshop on Debt, organized by Rosa Luxemburg Stiftung, Berlin, November 2012, http://debt-issues.blog.rosalux.de.

20. $\hookleftarrow$ Antonio Sanabria, “¿Cuál es el papel de los bancos en la crisis?,” in Bibiana Medialdea, ed., ¿Quiénes son los mercados y cómo nos gobiernan? (Barcelona: Icaria, 2011), 40.

21. $\hookleftarrow$ Vicenç Navarro, Juan Torres, Alberto Garzón, Hay alternativas. Propuestas para crear empleo y bienestar social en España (Madrid: Sequitur, 2011).

22. $\hookleftarrow$ Data drawn from the Spanish Active Population Survey.

23. $\hookleftarrow$ Industry and the construction sector, which suffered the hardest impacts of the early stages of the current crisis and are particularly masculinized, have lost 1,583,200 and 1,149,000 male jobs respectively since the third quarter of 2008 . Calculated by the author using data from the Spanish Active Population Survey.

24. $\hookleftarrow$ Ezquerra, "Crisis desiguales," "Women's Crises," and "Crisis de los cuidados y crisis sistémica."

25 . $\hookleftarrow$ The Ageing Index is the result of dividing the total amount of people who are above sixty-fouryears old by the total amount of people younger than sixteen-years old. It is published every year by the Spanish National Institute of Statistics.

26. $\hookleftarrow$ The Elderly Dependency Rate is the result of dividing the total amount of people who are older than sixty-four years old by the total amount of people who are between sixteen- and sixty-four years old. It is published every year by the Spanish National Institute of Statistics.

$27 . \hookleftarrow 1975-2012$, Basic demographic indicators of the Spanish National Institute of Statistics.

28. $\hookleftarrow$ See Lina Gálvez \& Mauricio Matus, Impacto de la Ley de Igualdad y la conciliación de la vida laboral, familiar y personal en las empresas andaluzas (Sevilla: Fundación de Estudios Sindicales, 2010). Time Use Surveys started to be conducted in Spain in 2002 and after that there has only been the 2009-2010 one. The little availability of time use data, as well as the great periods of time between the two editions, force us to read them quite cautiously. In addition, the fact that most official data published in Spain focus on the labor market makes it quite difficult to reach a global and complex understanding of the impacts of the crisis on women.

29. $\hookleftarrow$ On unpaid house work, see Gálvez and Torres, Desiguales; on the total work burden, see Lina Gálvez and Mauricio Matus, Impacto de la Ley de Igualdad y la conciliación de la vida laboral, familiar y personal en las empresas andaluzas (Seville: Secretaría de la Mujer de CCOO Andalucía-Fundación de Estudios Sindicales, 2011).

30. $\hookleftarrow$ LeBaron and Roberts, "Toward a Feminist Political Economy of Capitalism and Carcerality."

31. $\hookleftarrow$ Maliha Safri and Julie Graham, "The Global Household: Toward a Feminist Postcapitalist International Economy," Signs 36, no. 1 (Autumn 2010): 99-125; Amaia Pérez Orozco, "Crisis multidimensional y sostenibilidad de la vida," 35.

32. $\hookleftarrow$ Amaia Pérez Orozco, "Crisis multidimensional y sostenibilidad de la vida," Investigaciones Feministas 2 (December 2011): 35.

33. $\hookleftarrow$ Cindi Katz, "Messing with the 'Project"' in Castree and Gregory, eds., David Harvey: A Critical Reader.

34. $\hookleftarrow$ These alliances are not new. Silvia Federici explains how modern-age witch hunting was the main means to conduct a broad restructuring of sexual life to adjust it to the new capitalist discipline of labor and criminalize any sexual activity that threatened procreation, the transmission of property within the family, or took time and energy away from work. Federici, Caliban and the Witch, 194. 
35. $\hookleftarrow$ Pablo Carmona, Beatriz García, Almudena Sánchez, Spanish Neocon. La revuelta conservadora de la derecha española (Madrid: Traficantes de Sueños, 2012).

36. $\hookleftarrow$ Originally at http://tvelmundo .es/index.php/component/k2/item/36-la-mujer-tiene-que-volver-alhogar; see "Para Indignarse," April 16, 2012, http://rivas .tomalosbarrios.net. For the return to motherhood, see Charo Noguera, "De la mujer-mujer a la mujer-madre," El País, July 29 2012, 36-37, http://sociedad.elpais.com.

37. $\hookleftarrow$ V.G.C., "Y, en plena tormenta, el aborto" (comment), El País, August 4 2012, 11.

38. $\hookleftarrow$ Pablo Carmona, et. al., Spanish Neocon, 205.

All Material copyright @ 2014 Monthly Review. 